\title{
RELATIONSHIP OF PHYSICAL ACTIVITY TO TOTAL FAT MASS OF LECTURERS AND EMPLOYEES BENGKULU UNIVERSITY
}

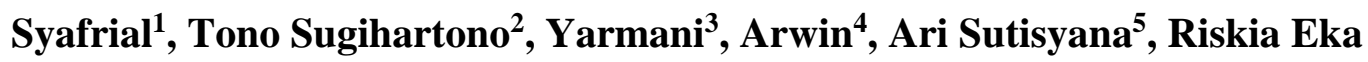

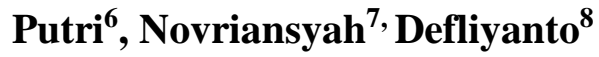 \\ ${ }^{12345678}$ Physical Educations, Universitas Bengkulu, Bengkulu, Indonesia
}

\section{Article Info \\ Article History: \\ Received March 2020 \\ Revised Juni 2020 \\ Accepted August 2020 \\ Available online September 2020}

Keywords:

Physical activity, total fat mass, Bioelectrical Impedance Analysis

\begin{abstract}
Insufficient physical activity and accumulation of body fat mass are risk factors for chronic disease. Physical activity is needed to prevent the risk of chronic disease due to body fat accumulation. This research is an observational analytic study with a cross sectional design. A sample of 52 people was taken by consecutive sampling method including lecturers and employees aged 30-60 years at the Faculty of Teacher Training and Education, University of Bengkulu (FKIP UNIB). Physical activity was analyzed using the Physical Activity Level (PAL) questionnaire, total fat mass was assessed by means of Bioelectrical Impedance Analysis (BIA). Data distribution analysis was tested using the Kolmogorov-Smirnov test. Analysis of the relationship between two categorical variables with the Chi-square test, the Kruskal-Wallis and Mann Whitney test. The correlation analysis between the two variables was analyzed using the Gamma correlation test. The results of this study indicate that there is a significant relationship between physical activity and total fat mass $(\mathrm{p}=0.031, \mathrm{r}=0.428)$ after being analyzed with Gamma correlation. It can be concluded that physical activity has a relationship with total fat mass.
\end{abstract}

\footnotetext{
Corresponding address : Jln Pd. Bulat, Limun Cage, Bengkulu City

Email
}

ISSN 2685-6514 (online)

ISSN 2477-331X (print)

DOI : $10.33369 / \mathrm{jk} . v 4 \mathrm{i} 2.10573$ 


\section{INTRODUCTION}

Physical activity is any movement of the body produced by skeletal muscles that requires energy expenditure, while temporary activity is the behavior of sitting or lying down at work (working at a computer, reading, etc.), but does not include sleeping time. Inadequate physical activity without a decrease in food intake can also lead to accumulation of body fat mass.

Nasution and Fatmah (2011) conducted a cross-sectional study to analyze the relationship between body fat percentage and risk factors. Based on the study, it was found that there was a significant relationship between the percentage of body fat and its risk factors ( $p$ <0.001). Subjects at risk of having a high percentage of fat mass are urban people, female, aged 55-65 years, with low educational status, unemployment, and light or moderate physical activity.(Nasution \& Fatmah, 2011).

Lecturers and employees of the Faculty of Teacher Training and Education, University of Bengkulu (UNIB) are a group with an average age of 30-60 years, so they are an age group that is prone to increasing body fat mass. Lecturers and employees are also included in the office worker group with a tendency of temporary and static daily activities, so the risk of experiencing a higher accumulation of fat mass.

Based on the theoretical study above, the researcher will conduct a preliminary study on the relationship between physical activity and the total fat mass of lecturers and employees at the University of Bengkulu.

\section{METHODS}

This study was an observational analytic study with a cross sectional design.The target population in this study were all lecturers and employees at Bengkulu University. The research samples were lecturers and staff aged 3060 years at the Faculty of Teacher Training and Education, Bengkulu University who met the inclusion criteria. The sample of this study amounted to 52 people.

Samples who have received an explanation of the research objectives, filled out and signed an informed consent form will be reconfirmed that the subject really did not eat, drink, and exercise 4 hours before the study was carried out. Next will be interviewed to obtain basic characteristic data in the form of age, sex, occupation, medical history, history of drug consumption, history of menstruation, and impaired mobility, and physical activity. Measurement of total fat mass was carried out using BIA brand Omron Karada Scan HBF-375 by adjusting the subject's age, sex, and height first.

\section{RESULT}

1. Level of Physical Activity of Research Subjects

The physical activity level of research subjects was calculated using the Physical Activity Level (PAL) questionnaire by interviewing the research subjects directly. The average score of the physical activity of the research subjects was 1.79 with the most physical activity being light and moderate physical activity scores. 
2. Total Fat Mass of Research Subjects

Measurement of visceral fat mass and total fat mass were measured using the Omron Karada Scan HBF-375 brand of Bioelectrical Impedance Analysis (BIA).

Table 1. Average and Distribution of Visceral Fat Mass and Total Fat Mass of Subjects Research $(n=52)$.

Massas

Total Fat Mass (\%) $29.49 \pm 7.22 * * *$

- Low $6(11.5 \%) * *$

- Normal $15(28.8 \%) * *$

- High $6(11.5 \%) * *$

- Very high $25(48.1 \%) * *$

Table 1. displays the percentage of total fat mass of the study subjects. The mean total fat mass had a mean of $29.49 \%$. The research subjects had a very high percentage of total fat mass $(48.1 \%)$. Above is the result of the analysis of the relationship between physical activity and total fat mass using the Chi-Square test, but based on the statistical results, it was found that 7 cells had an expected count value $<5$, so the Kruskal-Wallis and Mann Whitney tests would be performed. Description: Kruskal-Wallis test. Post hoc Mann-Whitney test: Low vs normal $\mathrm{p}=$ 0.677 ; Low vs high - very high $\mathrm{p}=0.385$; Normal vs high - very high $\mathrm{p}=0.027$. Data are presented in Median (Minimum - Maximum).

It was found that most of the research subjects had high-very high total fat mass ( 31 people). The results of the analysis showed that statistically there was no difference in total fat mass between groups on physical activity ( $\mathrm{p}=$ 0.077), but it was found that the difference in total fat mass between the normal groups and the height of the samples was very high $(\mathrm{p}=0.077)$. The results of the Chi-Square test of the relationship between physical activity and total fat mass after cell merging. The test results showed that the research subjects had more high total fat mass - very high with moderate physical activity levels (13 people). The results showed that there was no significant relationship between physical activity and the total fat mass of the study subjects $(p=0.262)$.

This study also conducted a gamma correlation test between physical activity and fat mass, statistical analysis showed that there was a significant relationship between physical activity and total fat mass $(p=0.031)$ with a positive correlation value and moderate correlation strength $(r=0.428)$. A positive value indicates that the higher the physical activity, the higher the percentage of total fat mass.

\section{DISCUSSION}

1. Level of Physical Activity of Research Subjects

The mean score of the physical activity of the research subjects with the measurement of Physical Activity Level (PAL) was $1.79 \pm 0.25$. The number of research subjects who have light activity and moderate activity is more than the research subjects who have heavy physical activity. This is in line with the dataBasic Health Research, (2014) that most of the adult population in Indonesia has less active physical activity 
(26.1\%).Adults are advised to do moderate intensity aerobic physical activity $\geq 30$ minutes per day for 5 times a week or to do aerobic physical activity with heavy intensity $\geq 20$ minutes per day for 3 times a week. Individuals can also do physical activity by combining strenuous physical activity and moderate physical activity in a week. If a person does regular physical activity, it can improve individual health, reduce the risk of chronic disease and disability, and prevent high weight gain.(Haskel et al., 2007).

\section{Average Total Fat Mass of Research Subjects}

The mean percentage of total fat mass in the study subjects was $29.49 \pm$ $7.22 \%$. The normal total fat mass of a man is $20.0-29.9 \%$ while the normal total fat mass of a woman is $10.0-19.9 \%$. Most of the study subjects had very high total fat mass.Heitmann, Erikson, Ellsinger, Mikkelsen, \& Larsson, (2000) stated that high levels of body fat were significantly associated with an increase in total mortality by $40 \%$.

In a study of women in Gothenburg, it was found that patients with diabetes for 12 years had three times the body fat mass. Segal et al. also suggests the relationship between body fat mass and mortality rates that the increase in body fat mass is closely related to an increase in blood pressure, cholesterol levels, and glucose levels.

3. Relationship between physical activity and total fat mass of research subjects
The percentage of total fat mass in the research subjects was found to be very high. Statistically, there was an insignificant relationship $(p=0.077)$ between physical activity and the total fat mass of the study subjects. This is in line with the results of the research conductedbyArchilona, (2014)that there was no significant relationship between physical activity and the percentage of total fat $(\mathrm{p}=0.241)$. The results also showed a significant positive correlation with moderate strength $(\mathrm{r}=0.428 ; \mathrm{p}=$ 0.031).

Research resultFitri, Mulyani, Fitrianingsih, \& Suryana (2016), states that physical activity that is carried out properly and regularly has an impact on a better and more balanced body composition. This makes the body healthier and fitter so that someone becomes more productive. The statement is in line with the research conductedRanggadwipa, (2014) states that there is a significant relationship between physical activity and body fat mass. Adriani \& Wirjatmadi, (2012) revealed his theory that low activity in adolescent groups will increase the risk of over nutrition due to lower energy expenditure and will lead to fat accumulation in adipose tissue.

\section{CONCLUSION}

The average level of physical activity for lecturers and staff at the Faculty of Teacher Training and Education, University of Bengkulu was the level of mild-moderate physical activity, with a mean PAL value of $1.79 \pm$ 0.25 . Most of the subjects in this study had a very high percentage of total fat mass, with an average percentage of total fat mass of $29.49 \pm 7.22 \%$. There was a 
significant relationship between physical activity and total fat mass, with a moderate positive correlation $(\mathrm{r}=0.428$, $\mathrm{p}=0.031)$.

\section{Suggestion}

In this study, the researchers suggested that further research with a larger sample size should be carried out. Researchers also suggest that the sample selection criteria should be uniform, for example, uniformity of species gender, a follow-up study was conducted by paying attention to the type and intensity of physical activity carried out by the research sample and a survey of variables which were risk factors for body fat mass.

\section{REFERENCES}

Adriani, M., \& Wirjatmadi, B. (2012). Peranan Gizi dalam Siklus Kehidupan. Jakarta: Kencana Prenada Media.

Anam, M. S., Mexitalia, M., Widjanarko, B., Pramono, A., Susanto, H., \& Subagio, H. W. (2016). Pengaruh Intervensi Diet dan Olah Raga Terhadap Indeks Massa Tubuh, Lemak Tubuh, dan Kesegaran Jasmani pada Anak Obes. Sari Pediatri, 12(1), 36-41.

Archilona, Z. (2014). Hubungan antara indeks massa tubuh (IMT) dengan kadar lemak total: Studi Kasus Pada Mahasiswa Kedokteran Undip. Jurnal Media Medika Muda.

Dasar, R. K. (2014). Badan Penelitian dan Pengembangan Kesehatan. Kementerian Kesehatan RI.

Fitri, Y., Mulyani, N., Fitrianingsih, E., \& Suryana, S. (2016). Pengaruh pemberian aktifitas fisik (aerobic exercise) terhadap tekanan darah, IMT dan RLPP pada wanita obesitas. Aceh Nutrition Journal., 1(2), 105-110.

Habut, M. Y., Nurmawan, I. P. S., \& Wiryanthini, I. A. D. (2016). Hubungan indeks massa tubuh dan aktivitas fisik terhadap keseimbangan dinamis pada mahasiswa fakultas kedokteran Universitas Udayana. Majalah Ilmiah Fisioterapi Indonesia, 2(1).

Haskel, W., Lee, I., Pate, R., Powell, K., Blair, S., Franklin, B., \& Bauman, A. (2007). Physical activity and public health: updated recommendation for adults from the american college of sports medicine and the american heart association. Circulation, 116(9), 10811093.

Heitmann, B., Erikson, H., Ellsinger, B., Mikkelsen, K., \& Larsson, B. (2000). Mortality associated with body fat, fatfree mass and body mass index among 60-year-old Swedish men $Đ$ a 22-year follow-up: The study of men born in 1913. International Journal of Obesity, 24, 33-37.

Nafilah, N., \& Fitranti, D. Y. (2014). Hubungan Indeks Massa Tubuh (Imt), Persen Lemak Tubuh, Asupan Zat Gizi, Dan Aktivitas Fisik Dengan Kepadatan Tulang Pada Remaja Putri (Doctoral dissertation, Diponegoro University).

Nasution, Y., \& Fatmah. (2011). Light physical activity increased body fat percentage in elderly Javanese. Universa Medicina, 1(30), 45-53.

Oktaviani, W. D. (2012). Hubungan kebiasaan konsumsi fast food, aktivitas fisik, pola konsumsi, karakteristik remaja dan orang tua dengan indeks massa tubuh (IMT)(studi kasus pada siswa SMA Negeri 9 Semarang tahun 2012). Jurnal Kesehatan Masyarakat Universitas Diponegoro, 1(2), 18843.

Prasetio, E., Sutisyana, A., \& Ilahi, B. R. (2017). Tingkat Kebugaran Jasmani Berdasarkan Indeks Massa Tubuh Pada Siswa SMP Negeri 29 Bengkulu Utara. Kinestetik: Jurnal Ilmiah Pendidikan Jasmani, 1(2), 86-91.

Putri, R. E. (2019). Hubungan aktivitas fisik terhadap massa lemak tubuh dan lingkar pinggang pada karyawan. SKRIPSI2018.

Ranggadwipa, D. D. (2014). Hubungan Aktivitas Fisik Dan Asupan Energi Terhadap Massa Lemak Tubuh Dan Lingkar Pinggang Pada Mahasiswa 
Fakultas Kedokteran Universitas

Diponegoro. DIPONEGORO

MEDICAL JOURNAL.

Setiowati, A. (2014). Hubungan Indeks

Massa Tubuh, Persen Lemak Tubuh,

Asupan Zat Gizi dengan Kekuatan

Otot. Media Ilmu Keolahragaan

Indonesia, 4(1). 